\title{
Nitrogen and phosphorus fertilization increases the uptake of soil heavy metal pollutants by plant community
}

\section{Guangmei Tang}

Yunnan University

\section{Xiaole Zhang}

Chuxiong Normal University

\section{Lanlan Qi}

Yunnan Normal University

\section{Chenjiao Wang}

Yunnan Normal University

Lei Li

Yunnan Normal University

Jiahang Guo

Yunnan Normal University

\section{Xiaolin Dou}

Research Centre for Eco-Environmental Sciences Chinese Academy of Sciences

\section{Meng Lu}

Yunnan University

Jingxin Huang ( $\square$ huangjingxin17@163.com )

Yunnan University https://orcid.org/0000-0001-5641-2731

\section{Research}

Keywords: soil heavy metals pollution, phytoremediation, nitrogen and phosphorus fertilizer

Posted Date: April 19th, 2021

DOI: https://doi.org/10.21203/rs.3.rs-413625/v1

License: (c) (i) This work is licensed under a Creative Commons Attribution 4.0 International License.

Read Full License 


\section{Abstract}

Background: Soil heavy metal pollution is widespread around the world. Heavy metal pollutants are easily absorbed by plants and enriched in food chain, which may harm human health, cause the loss of plant, animal and microbial diversity. Plants can generally absorb soil heavy metal pollutants. Compared with hyperaccumulation plants, non-hyperaccumulator plant communities have many advantages in the remediation of heavy metals pollution in soil. However, the amount of heavy metals absorbed could be less, and the biomass would be reduced under heavy metal pollution. The application of nitrogen $(\mathrm{N})$ and phosphorus $(\mathrm{P})$ is inexpensive and convenient, which can increase the resistance of plants to adversity and promote the growth of plants of heavy metal polluted soils.

Methods: We designed a comparative greenhouse experiment with heavy metal contaminated soils, and set up four treatments: CK treatment (soil without fertilizer), $\mathrm{N}$ treatment (soil with $\mathrm{N}$ addition), $\mathrm{P}$ treatment (soil with $\mathrm{P}$ addition), and $\mathrm{N}+\mathrm{P}$ treatment (soil with $\mathrm{N}$ and $\mathrm{P}$ addition).

Results: Our results showed that plant aboveground biomass were $231.17 \%, 14.84 \%, 269.86 \%$ greater than CK treatment, respectively. $\mathrm{N}$ and $\mathrm{P}$ fertilizer stimulated plants to allocate more biomass to the aboveground parts. In addition, $\mathrm{N}$ treatments significantly reduced the content of $\mathrm{Cd}$ in aboveground and belowground biomass of plants $(P<0.05)$; $\mathrm{P}$ fertilizer significantly decreased the content of $\mathrm{Cu}$ in aboveground biomass $(P<0.05)$. N+P treatments significantly reduced the content of $\mathrm{Cd}, \mathrm{Cu}$ in aboveground and belowground biomass of plants $(P<0.05)$. Meanwhile, $\mathrm{N}$ and $\mathrm{N}+\mathrm{P}$ significantly increased the accumulation $\left(\mathrm{mg} / \mathrm{m}^{2}\right)$ of $\mathrm{Cd}, \mathrm{Cu}$, and $\mathrm{Pb}$ in plant aboveground biomass $(P<0.05)$. $\mathrm{N}$ and $\mathrm{N}+\mathrm{P}$ fertilizer increased aboveground-belowground heavy metals accumulation ratio $(P<0.05)$, promoting plants to uptake more heavy metal pollution out of soil.

Conclusions: $\mathrm{N}$ and $\mathrm{P}$ fertilizer increased the accumulation of heavy metals in aboveground of the natural plant community and accelerated the absorption of heavy metals by plants, and $\mathrm{N}$ fertilizer had a better effect. Our results provide an inexpensive method for remediation of heavy metal pollution in low economic value soils, such as contaminated farmland, abandoned land and mine tailings, etc.

\section{Background}

Heavy metal pollution in farmlands is usually caused by the improper disposal of industrial and domestic wastes, and by contaminated sewage irrigation and fertilization, which is widespread around the world [1], and has been frequently reported in European Union, India, the United States, and China [2]. Heavy metal pollutants in soils are easily absorbed by plants, and then enriched in food chain, which could affect animal nerves, liver, bones, etc. It was reported that farmland soil heavy metal pollution also causes some cancers of human beings, like upper gastrointestinal cancers [3], lung, liver, bladder, colon, and skin cancer [4]. Heavy metal pollution also affects the metabolism, heredity and reproduction of life through its toxic effects, leading to the loss of plant, animal and microbial diversity. It was reported that soil heavy metals reduced the microbial diversity by $99.5 \%$ [5], resulting in the death of sensitive plants 
and affecting plant community composition. Heavy metal pollution also affects the substance cycling, energy conversion and ecosystem function. Human intervention is an important method to reduce the impact of heavy metal pollution.

Human intervention can remove or alleviate the harm of heavy metal pollutants in soil, therefore soil leaching, solidification and stabilization are usually used for the remediation of heavy metal polluted soils, yet these methods are not suitable for agricultural, forestry, abandoned land and other low commercial value soils for their high economic cost[6]. Phytoremediation is a method to remove heavy metal pollutants from soil by harvesting the aboveground biomass which had absorbed soil heavy metals [7-9]. It is an environmentally friendly method for soil heavy metal remediation without damaging the cultivability of soils $[10,11]$. Phytoremediation usually use hyperaccumulated plants as this type of plants can enrich high concentrations of heavy metals in their tissue. However, phytoremediation requires a series of steps, such as thoroughly removal of original plants, planting of hyperaccumulated plants and follow-up management, etc. which requires a lot of manpower and economic investment [12]. Meanwhile, a number of studies have reported that hyperaccumulators usually grew slowly and had low biomass production $[8,13]$. Plants can generally uptake heavy metal pollutants [14] and non-hyperaccumulator plant communities have the ability to absorb heavy metals in soils [15]. Maric et al. proved that 17 kinds of wild plants can absorb $\mathrm{Pb}, \mathrm{Cu}$, and $\mathrm{Fe}$ in soil through cultivation experiments [16]. Although some plants are not able to enrich high concentrations of heavy metal pollutants in tissue such as hyperaccumulators, they can absorb more heavy metal pollutants in soil by large planting area, long-term plantation and harvesting [17]. However, there are few studies focusing on how to improve the tolerance and absorption of heavy metals of plant communities.

Nitrogen $(\mathrm{N})$ and phosphorus $(\mathrm{P})$ are limiting nutrient element in most ecosystems. Application of $\mathrm{N}$ and $P$ can significantly stimulate plant growth $[18,19]$, and increase the biomass of plant community [20]. N and $P$ fertilizers are inexpensive and easy to obtain, and are commonly used in agricultural production and vegetation restoration of the disturbed ecosystems [21-23]. Phytoremediation is usually carried out by harvesting the aboveground biomass of plants, and the application of $\mathrm{N}$ in the plant community can increase the aboveground biomass of herbs, shrubs, conifers and broad-leaved plants [24-26]. Besides, it is beneficial to plant restoration by harvesting more aboveground biomass. $\mathrm{N}$ and $\mathrm{P}$ can also increase the adaptability of plants to the adverse and improve the ability of antioxidant system of plant [27]. It was reported that $\mathrm{N}$ addition increased the contents of proline and peroxidase in plants, and enhanced the drought resistance and growth performance of plants [28]. Our previous study also found that $\mathrm{N}$ and $\mathrm{P}$ fertilizer in low level $N$ and $P$ soils could restore plant diversity of heavy metal polluted soils [21], possibly due to that $\mathrm{N}$ and $\mathrm{P}$ fertilizer increased the tolerance of plants to heavy metal stress [29]. For instant, Zhang et al. [30] found that increasing $\mathrm{NO}_{3}{ }^{-}$can improve the tolerance of Arabidopsis thaliana to $\mathrm{Cd}$ stress. Zhang's study reported that appropriate concentrations of $\mathrm{N}$ and $\mathrm{P}$ could increase the activity of antioxidant enzymes and reduce the toxicity of heavy metals [31]. Therefore, we speculated that the application of $\mathrm{N}$ and $\mathrm{P}$ will increase the efficiency of phytoremediation of heavy metal polluted soils. 
To test our speculation, we conducted a comparative experiment in greenhouse to study the effect of $\mathrm{N}$ and $\mathrm{P}$ in phytoremediation of heavy metal pollution soil. Our results may provide an inexpensive approach for remediation of contaminated farmland, abandoned land, tailings and other low commercial value soil heavy metal pollutions.

\section{Methods}

\section{Sample}

The sampling site of this study is located in Kunming, Yunnan Province, China. This region belongs to a subtropical monsoon climate, and the soil type is acid red soil. The sampling site was abandoned for more than 10 years. The plants in this plot were mainly perennial and annual herbs, including Bidens bipinnata, Euphorbia australis, Setaria Setaria, etc. Our study was begun in November 2018. The plant seed bank of natural plant community was collected by transect method. The specific steps of soil seed bank sampling are as follows: we set up a $500 \mathrm{~m}$ sampling line in the sampling site. On this sampling line we further set up 10 sampling plots, and the distance of two adjacent plots were $50 \mathrm{~m}$ apart. The size of each sampling plot is $1 \times 1 \mathrm{~m}$, and $0-2 \mathrm{~cm}$ soil in each sample plot was collected.

\section{Greenhouse design}

Soils obtained from seed bank collection were used for cultivation experiment. These soils were air dried to $20 \%$ water content, and the debris, animal and plant residues were carefully removed. After the soils were crushed and passed through a $5 \mathrm{~mm}$ sieve, these soils were weighed and put into 20 pots $(49 \mathrm{~cm} \times$ $18 \mathrm{~cm} \times 14 \mathrm{~cm}$ ), and each pot was loading $7 \mathrm{~kg}$ soils. To simulate the heavy metal pollution, $\mathrm{Cu}^{2+}, \mathrm{Cd}^{2+}$ and $\mathrm{Pb}^{2+}$ were added into the 20 pots with the concentration of $50 \mathrm{mg} / \mathrm{kg}, 10 \mathrm{mg} / \mathrm{kg}$ and $20 \mathrm{mg} / \mathrm{kg} . \mathrm{In}$ order to verify the role of $\mathrm{N}$ and $\mathrm{P}$ in the ecological restoration of heavy metal polluted soil, four treatments were set up as follows. Control treatment (CK): soil with heavy metals addition but without $\mathrm{N}$ and $P$ fertilizer. Nitrogen fertilizer treatment (NF): soil with heavy metals and fertilized with $30 \mathrm{mg} \mathrm{N} / \mathrm{kg}$ soil; Phosphorus fertilizer treatment (PF): soil with heavy metals and fertilized with $10 \mathrm{mg} \mathrm{P} \mathrm{/} \mathrm{kg} \mathrm{soil;}$ Nitrogen and phosphorus fertilizer treatment (NPF): soil with heavy metals and fertilized with $30 \mathrm{mg} \mathrm{N} /$ $\mathrm{kg}$ and $10 \mathrm{mg} \mathrm{P} / \mathrm{kg}$ soil. In our study, each treatment had 5 replicates, except for the treatment applied fertilization in this study, other treatments were identical of all replication. Except for the above treatments, the daily management method of each pot of soil in our study was exactly the same. Our study was ended in October 2019, four treatments totally included 16 types of plant, among which Bidens bipinnata, Euphorbia australis, Echinochloa crusgalli were the dominant species. The plants aboveground and belowground biomass was determined by the following method: the whole plant was harvest of all replications. Soil attached to the root was gently shaken off to avoid loss of biomass. Plant biomass was further cleaned up carefully with tap water in the laboratory. Then it was filled in envelope and dried with a drying oven at $72{ }^{\circ} \mathrm{C}$ for $48 \mathrm{~h}$. The dried plant biomass of all replications was separated into aboveground and belowground part, and weighed respectively. 


\section{Determination of plant heavy metals content}

Then aboveground and belowground biomass was cut into pieces to determine the heavy metals content in plants. The methods of measuring plant heavy metals content are as follows: The plant material of a replication was mixed thoroughly, grinded into powder, and sifted through a 100-mesh sieve, then $0.2 \mathrm{~g}$ plant powder was digested with $10 \mathrm{ml}(16 \mathrm{~mol} / \mathrm{L}) \mathrm{HNO}_{3}$ and $(12 \mathrm{~mol} / \mathrm{L}) \mathrm{HCl}$ mixed solution using a Microwave Digestion System (Touchwin2.0) produced by Aopule Technology Group (Chengdu) Co Ltd. After the plant powder has been digested completely, the volume was adjusted to $50 \mathrm{ml}$ using $5 \% \mathrm{HNO}_{3}$, and the content of heavy metals is determined using an Atomic Absorption Spectrophotometer (AA-7000) Itd. Japan. In our study, plant $\mathrm{Cd}, \mathrm{Cu}$ and $\mathrm{Pb}$ contents were determined.

\section{Determination of soil properties}

Soils attach to plant root were collected to determine the soil properties. Soil pH was analyzed as follows: First extracting $10 \mathrm{~g}$ of soil powder with $10 \mathrm{ml}$ deionized water, and measuring soil pH by a pH meter. Soil $\mathrm{NO}^{-}$and $\mathrm{NH}_{4}^{+}$were analyzed by following methods: First extracting $10 \mathrm{~g}$ of soil powder with $100 \mathrm{ml}$ $(1 \mathrm{~mol} / \mathrm{L}) \mathrm{KCl}$, and the solution was filtered after shaking 1 hour. Determination of soil $\mathrm{NO}^{-}$and $\mathrm{NH}^{+}$ using Seal Analytical (AA3), Itd. Germany, which is based on the standard LY/T 1228-2015. Available phosphorus was analyzed by spectrophotometry, extracted with $\mathrm{NH}_{4} \mathrm{~F}$ solution and determined by molybdenum, antimony and scandium colorimetry (NY/T 1121.7-2014).

\section{Data Analysis}

(1) Calculation of plant heavy metal enrichment:

$\mathrm{H}_{\mathrm{e}}=\mathrm{H}_{\mathrm{con}}{ }^{*} \mathrm{~W}_{\mathrm{ab}}$

$\mathrm{H}_{\mathrm{e}}$ : heavy metals enrichment in plant biomass

$\mathrm{H}_{\text {con }}$ : heavy metal content in aboveground biomass

$\mathrm{W}_{\mathrm{ab}}$ : weight of aboveground biomass

(2) Calculation of plant aboveground and belowground heavy metal accumulation ratio:

$\mathrm{R}_{\mathrm{ab}}=\mathrm{H}_{\mathrm{ea}} / \mathrm{H}_{\mathrm{eb}}$

$R_{a b}$ : Aboveground biomass and belowground biomass heavy metals enrichment ratio

$H_{e a}$ : Heavy metals enrichment in Aboveground biomass

$H_{\mathrm{eb}}$ : Heavy metals enrichment in belowground biomass 
We used SPSS Statistics (25.0) software to analyze the differences of soil properties, plant biomass, plant heavy metal content, quality of plant heavy metals enrichment among different treatments, and conducted one-way ANOVA and Duncan multiple comparisons for comparative analysis. Microsoft excel 2016 was employed to make charts.

\section{Results}

\section{Effects of different treatments on soil properties}

Soil properties of different treatments were showed in Table 1. Soil pH, $\mathrm{NH}_{4}{ }^{+}$indicated no significant difference among all treatment $(P>0.05)$. Treatments with $\mathrm{N}$ fertilizer had a higher $\mathrm{NO}_{3}{ }^{-}$content $(P<$ 0.05), and treatments with $P$ fertilizer had a higher available $P$ content $(P<0.05)$.

Table 1 Soil properties of under different treatments.

\begin{tabular}{ccccc}
\hline Treatments & $\mathrm{pH}$ & $\begin{array}{c}\mathrm{NH}_{4}{ }^{+} \\
(\mathrm{mg} / \mathrm{kg})\end{array}$ & $\begin{array}{c}\mathrm{NO}_{3}{ }^{-} \\
(\mathrm{mg} / \mathrm{kg})\end{array}$ & $\begin{array}{c}\text { Available P } \\
(\mathrm{mg} / \mathrm{kg})\end{array}$ \\
\hline $\mathrm{CK}$ & $6.42 \pm 0.17 \mathrm{a}$ & $0.82 \pm 0.13 \mathrm{a}$ & $5.05 \pm 1.44 \mathrm{~b}$ & $4.10 \pm 0.26 \mathrm{~b}$ \\
$\mathrm{~N}$ & $6.17 \pm 0.22 \mathrm{a}$ & $0.96 \pm 0.10 \mathrm{a}$ & $16.41 \pm 0.13 \mathrm{a}$ & $6.05 \pm 0.91 \mathrm{~b}$ \\
$\mathrm{P}$ & $6.30 \pm 0.11 \mathrm{a}$ & $0.61 \pm 0.07 \mathrm{a}$ & $2.20 \pm 0.65 \mathrm{~b}$ & $11.55 \pm 2.96 \mathrm{a}$ \\
$\mathrm{N}+\mathrm{P}$ & $6.17 \pm 0.17 \mathrm{a}$ & $1.15 \pm 0.31 \mathrm{a}$ & $14.17 \pm 1.91 \mathrm{a}$ & $9.88 \pm 1.01 \mathrm{a}$ \\
\hline
\end{tabular}

\section{Effects of different treatments on the aboveground biomass}

Plant aboveground biomass of four treatments showed significant differences $(P<0.05), N+P$ treatment had the highest plant aboveground biomass, whereas CK treatment was the lowest. Plant aboveground biomass of $\mathrm{N}, \mathrm{P}$, and $\mathrm{N}+\mathrm{P}$ treatments were $231.17 \%, 14.84 \%, 269.86 \%$ of $\mathrm{CK}$ treatment, respectively. These results indicated that $\mathrm{N}$ and $\mathrm{P}$ significantly promoted plant growth, and $\mathrm{N}+\mathrm{P}$ had the highest effect (Fig. 1).

\section{Effect of different treatments on aboveground and belowground biomass ratio}

Plant aboveground and belowground biomass ratio (ABR) of four treatments showed significant differences $(P<0.05)$. $N$ treatment had the highest $A B R$, while $C K$ treatment had the lowest $A B R$. $A B R$ of $\mathrm{N}, \mathrm{P}$, and N+P treatments were $227.20 \%, 80.59 \%$ and $154.04 \%$ of CK treatment, respectively. These results suggested that $\mathrm{N}$ and $\mathrm{P}$ fertilizer stimulated plants to allocate more biomass to aboveground parts under heavy mental pollution (Fig. 2).

Effects of different treatments on aboveground and belowground biomass heavy metals content. 
$\mathrm{N}$ and $\mathrm{N}+\mathrm{P}$ treatments significantly decreased the content of $\mathrm{Cd}$ in aboveground and belowground biomass of plants $(P<0.05), P$ treatment tended to reduce the content of $C d$ in aboveground and underground parts of plants, though the effect was no significant $(P>0.05)$. $P$ and N+P treatment significantly lowered $C u$ content in aboveground and belowground biomass of plant $(P<0.05)$, and N+P treatment significantly decreased $\mathrm{Cu}$ content in belowground biomass of plant $(P<0.05)$. N, $P$ and N+P treatments tended to reduce the content of $\mathrm{Pb}$ in aboveground and belowground biomass, though it had no significant effect $(P>0.05$, Fig.3). These results indicated that $N$ and $P$ fertilizer reduced the content of $\mathrm{Cd}, \mathrm{Cu}$ and $\mathrm{Pb}$ pollutants by plant.

\section{Accumulation of heavy metals in aboveground biomass}

$\mathrm{Cd}, \mathrm{Cu}, \mathrm{Pb}$ accumulation in aboveground biomass showed significant increases under $\mathrm{N}$ and $\mathrm{N}+\mathrm{P}$ fertilizer addition $(P<0.01)$. Among 4 treatments, CK treatment accumulated the lowest quantity of $\mathrm{Cd}$, $\mathrm{Cu}, \mathrm{Pb}$. Two $\mathrm{N}$ fertilizer treatments, including $\mathrm{N}$ and $\mathrm{N}+\mathrm{P}$ treatments, accumulated significantly higher quantity of heavy metals $(P<0.01)$. P fertilizer slightly increased plant heavy metals accumulation, yet the effect was no significant. These results confirmed that $\mathrm{N}$ and $\mathrm{N}+\mathrm{P}$ fertilizer increased the accumulation of heavy metals in the aboveground parts of plants.

Plant aboveground and belowground heavy metals accumulation ratio among different treatments.

The accumulation ratio of $\mathrm{Cd}, \mathrm{Cu}, \mathrm{Pb}$ for plant aboveground and belowground part showed significant difference among 4 treatments $(P<0.01)$, whereas $\mathrm{N}$ and $\mathrm{N}+\mathrm{P}$ fertilizer had a similar effect. $\mathrm{N}, \mathrm{P}$, and $\mathrm{N}+\mathrm{P}$ fertilizer increased the proportion of heavy metals in aboveground parts of plant. The results implied that that $\mathrm{N}, \mathrm{P}$ and $\mathrm{N}+\mathrm{P}$ fertilizer stimulated plant to accumulate more heavy metal pollutants in plant aboveground parts (Fig. 5).

The influence of $\mathrm{N}, \mathrm{P}$ treatments and their interaction on the accumulation of heavy metals in plants

$\mathrm{N}$ fertilizer significant influenced the aboveground biomass, $\mathrm{ABR}$, heavy metal content and accumulation in aboveground biomass, and aboveground and belowground heavy metals accumulation ratio $(P<0.01)$. $P$ fertilizer significant affected aboveground and belowground biomass ratio, heavy metal content in aboveground biomass. $\mathrm{N}$ and $\mathrm{P}$ interaction significant impacted aboveground biomass, $\mathrm{Cd}$ and $\mathrm{Cu}$ content in both aboveground and belowground biomass, $\mathrm{Cd}, \mathrm{Cu}, \mathrm{Pb}$ accumulation in aboveground biomass, and aboveground and belowground heavy metals accumulation ratio $(P<0.05)$. These results suggested that $\mathrm{N}$ and $\mathrm{P}$ fertilizer increased the uptake of soil heavy metals by plant community, and the uptake effect was best when N, P fertilizers were applied at the same time(Table 2).

Table2 Summary of results from standard method of moments ANNOVA from aboveground biomass, aboveground to belowground biomass ratio, heavy metal content, aboveground heavy metal enrichment, and aboveground to underground heavy metal enrichment ratio response to experimental treatments. 


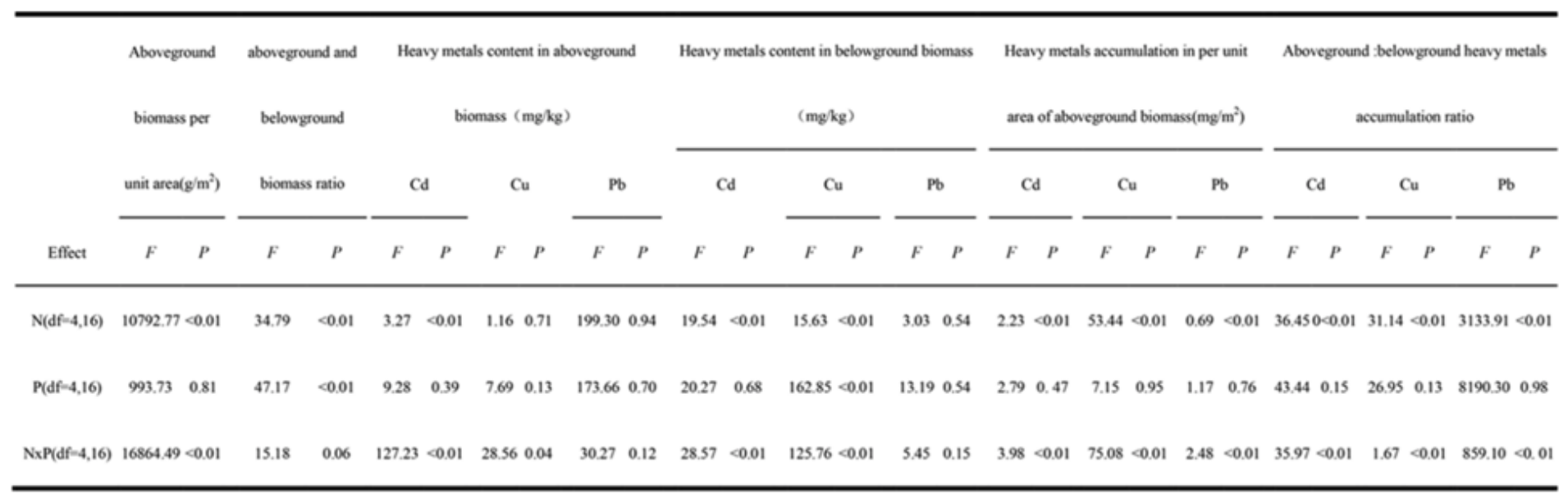

\section{Discussion}

Our results indicated that $\mathrm{N}, \mathrm{P}$ fertilizers increased the biomass of plant communities under heavy metal pollution (Fig. 1). $\mathrm{N}$ and $\mathrm{P}$ are the limiting nutrients in terrestrial ecosystem, which are supposed to significantly promote plant growth and biomass $[32,33]$. For instance, $\mathrm{N}$ or $\mathrm{P}$ increased plant community biomass at an alpine meadow in the Tibetan Plateau [34] and enhanced the biomass of the hyperaccumulator plant T.caerulescens [35, 36] and Pteris Vittata [37]. P application stimulated the plant biomass in alpine meadows [34] and typical temperate grasslands [20], and increased biomass and coverage of Cyanolichen Pseudocyphellaria [33]. The coupling of $\mathrm{N}$ and $\mathrm{P}$ nutrients are common in natural ecosystems. In our study, $\mathrm{N}$ and $\mathrm{P}$ applied at the same time had significant effects on plant growth and biomass (Fig. 1), and their interaction had a significant better effect (Table 2). Previous studies showed similar results, for instant, the combined $\mathrm{N}$ and $\mathrm{P}$ fertilizer had the greatest effect on the biomass of grass plants [38,39] and alpine meadow plants [40]. This may be because that $\mathrm{N}$ and $\mathrm{P}$ promoted photosynthesis and biomass accumulation of plant [28, 41, 42]. Other studies have found that $\mathrm{N}$ fertilizer improved the drought tolerance and growth performance of poplars [28], and reduced the toxicity of $\mathrm{Cd}$ to plant $[28,42]$. $\mathrm{N}$ and $\mathrm{P}$ addition might enhance plant antioxidant defense ability and the stress to adversity by showing increased level of free proline and carotenoid, which increases the plant's resistance to heavy metal pollutants $[43,44]$. Therefore, we speculate that these reasons might jointly promote the plant biomass under heavy metal pollution.

Our study found that the content of heavy metals $\mathrm{Cd}, \mathrm{Cu}$, and $\mathrm{Pb}$ of plant communities was reduced by adding $\mathrm{N}$ and $\mathrm{P}$ (Fig. 3). Previous research found $\mathrm{N}$ and $\mathrm{P}$ had different effects on the absorption of heavy metals by plants. Adding $\mathrm{N}$ and $\mathrm{P}$ promoted the absorption of $\mathrm{Cd}$ by Brassica napus [45] or inhibited the content of $\mathrm{Cd}$ in corn [46]. Fertilization also significantly reduced the content of $\mathrm{Cd}$ and $\mathrm{Pb}$ in rice [47], which was consistent with our results. A large number of studies have shown that fertilization reduced the bio-availability of heavy metals in soil, affecting the morphology and complexation of heavy metals, and thus influencing the movement of heavy metals to plant roots and the absorption of heavy metals $[48,49]$. In addition, our results suggested that $N$ and $P$ fertilizers are beneficial to increase the 
accumulation of heavy metals by plant communities, and the effect was highest as adding N (Fig. 4). Some other studies had similar results, such as $\mathrm{N}$ fertilizer increased hyperaccumulators Pteris Vittata [37] to accumulate heavy metals As; and increased hyperaccumulators Sedum alfredii Hance to accumulate of heavy metals $\mathrm{Cd}, \mathrm{Pb}$, and $\mathrm{Zn}$ [50]. In our study, $\mathrm{N}$ reduced the contents of heavy metals $\mathrm{Cd}$, $\mathrm{Cu}$, and $\mathrm{Pb}$ in plants by $31.49 \%, 8.42 \%$, and $1.28 \%$, respectively, but the biomass increased to $231.17 \%$. The stimulation of plant biomass was greater than the decrease in the content of heavy metals in plants under $\mathrm{N}$ and $\mathrm{P}$ fertilization (Fig. 1, Fig. 2), resulting in an increase in the accumulation efficiency of heavy metals. Other studies reported that $\mathrm{N}$ and $\mathrm{P}$ addition changed the morphology of heavy metals in soils, thus affecting the uptake and enrichment of heavy metals by plants [51, 52], which was consistent with our results.

Our results demonstrated that $\mathrm{N}$ and $\mathrm{P}$ fertilization increased ABR (Fig. 2) and enhanced the proportion of heavy metal enrichment in aboveground parts of plants (Fig. 5). In our study, N, P and N + P fertilizer stimulated the aboveground biomass by $231.17 \%, 14.84 \%$ and $269.86 \%$. The ABR of the plants increased after fertilization, which was similar to the Thornley model [53]. Other results from a meta-analysis also showed that $\mathrm{N}$ or $\mathrm{P}$ fertilizer increased the aboveground biomass ratio of many species [54], including maize [55], Sporobolus alterniflorus [26], alpine meadow plants on the Tibetan Plateau, etc [34]. This may be due to that the application of $\mathrm{N}$ and $\mathrm{P}$ fertilizer can enhance the photosynthesis of plants and promote plant to accumulate organic matter in aboveground part [28], thus increasing plant height, leaf length and stem length [25]. In our study, N + P fertilizer resulted in the highest $\mathrm{Cd}$ accumulation in aboveground biomass by $143 \%$. $\mathrm{N}$ fertilizer had the highest $\mathrm{Cu}$ and $\mathrm{Pb}$ accumulation in aboveground biomass, which were $244.02 \%$ and $236.26 \%$ increases, respectively (Fig. 4). It might be fertilizer indirectly impact the accumulation of heavy metals in plant by influencing soil pH, ionic strength, rhizosphere chemistry, microbial activity, which affected the absorption of heavy metals by plants [51,56]. Heavy metals plant remediation is usually carried out by harvesting the aboveground parts of plants and subsequent reprocessing. The increase of heavy metal enrichment in aboveground parts of plants may improve the efficiency of phytoremediation. Our results suggested that the application of $\mathrm{N}$ or $\mathrm{P}$ fertilizer could increase the efficiency of plant remediation of heavy metals in soil.

Soil heavy metal pollution is widespread and increasingly serious around the world [57]. Heavy metal pollution in low economic value soil such as farmland and abandoned land accounts for a large proportion of polluted soils, which leads to the quality reduction of a variety of agricultural products, harms human health and causes the loss of biodiversity [3, 4, 21]. Compared with high-cost methods such as leaching and other engineering remediation, the remediation of low economic value soils is usually carried out through phytoremediation. However, super-enriched phytoremediation requires a series of steps, such as thorough removal of original plants, cultivation and management, and therefore needs a large amount of manpower and economic investment. Our results showed that $\mathrm{N}$ and $\mathrm{P}$ fertilizer increased the accumulation of heavy metals in the aboveground parts of the natural plant community and accelerated the remediation of heavy metals in soil by plants, thus establishing a new approach for remediation of heavy metals in low economic value soils such as farmland and abandoned land. At the same time, fertilizer can not only improve the structure of organic matter and nutrient elements in 
grassland soil, balance the nutrient elements lost due to mowing and play an important role of nutrient replenishment, but also use natural plant community to avoid further cultivation and management process requirement by the use of super-enriched plants $[56,58]$. In the context of global soil heavy metal pollution, our results may have a certain practical value. Moreover, the mechanism of antagonistic and synergistic effects of heavy metals in plant, heavy metals and N, P elements still need to be further explored.

\section{Conclusions}

$\mathrm{N}$ and $\mathrm{P}$ fertilizer increased the accumulation of $\mathrm{Cd}, \mathrm{Cu}$, and $\mathrm{Pb}$ in aboveground of the natural plant community and accelerated the absorption of $\mathrm{Cd}, \mathrm{Cu}$, and $\mathrm{Pb}$ by plants, and $\mathrm{N}$ fertilizer had a better effect. Our results provide an inexpensive method for remediation of heavy metal pollution in low economic value soils, such as contaminated farmland, abandoned land and mine tailings, etc.

\section{Declarations}

\section{Authors' contributions}

XZ, LQ, and JH designed the study. GT analyzed the data and drafted the manuscript. XD and CW contributed to the data analysis and interpretation of data. LL and JG conducted measurements. ML and $\mathrm{JH}$ made key revisions and edits. All authors contributed in drafting and editing the manuscript and approved the final manuscript.

\section{Funding}

This work was supported by the National Natural Science Foundation of China (grant number: 31800443), the Yunnan Provincial Department of Education Fund (grant number: 2018JS144), the Scientific Research Foundation for introduced doctor of Yunnan normal university (grant number: 2017ZB021), the Second Tibetan Plateau Scientific Expedition and Research (STEP) program (grant number: 2019QZKK0308), the Thousand Young Talents Program of Yunnan Province, and Double Top University Plan Fund of Yunnan University (grant number: C176220100044).

\section{Availability of data and materials}

Data sharing not applicable to this article as no datasets were generated or analyzed during the current study.

\section{Ethics approval and consent to participate}

Not applicable.

\section{Consent for publication}


Not applicable.

\section{Competing interests}

The authors declare that they have no competing interests.

\section{Author details}

${ }^{1}$ Key Laboratory of Soil Ecology and Health in Universities of Yunnan Province, School of Ecology and Environmental Sciences, Yunnan University, Kunming, P.R. China. ${ }^{2}$ Yunnan Provincial Observation and Research Station of Soil Degradation and Restoration for Cultivating Plateau Traditional Chinese Medicinal Plants, Yunnan Normal University, Kunming, Yunnan, PR China. ${ }^{3}$ Chuxiong Normal University, School of Mathematics \& Statistics, Chuxiong, PR China. ${ }^{4}$ Research Center for Eco-Environmental Sciences, Chinese Academy of Sciences, Beijing, PR China

\section{References}

1. CHUNG BY, SONG CH, PARK BJ. CHO JY: Heavy Metals in Brown Rice(Oryza sativa L.) and Soil After Long-Term Irrigation of Wastewater Discharged from Domestic Sewage Treatment Plants. Pedosphere. 2011;21(05):621-7.

2. Tóth $\mathrm{G}$, Hermann T, Szatmári G, Pasztor L: Maps of heavy metals in the soils of the European Union and proposed priority areas for detailed assessment. Sci Total Environ 2016, 565(2016):1054-1062.

3. Türkdoğan MK, Kilicel F, Kara K, Tuncer I, Uygan I. Heavy metals in soil, vegetables and fruits in the endemic upper gastrointestinal cancer region of Turkey. Environ Toxicol Pharmacol. 2003;13(3):1759.

4. Carpenter RL, Jiang B-H. Roles of EGFR, PI3K, AKT, and mTOR in Heavy Metal-Induced Cancer. Curr Cancer Drug Targets. 2013;13(3):337-72.

5. Jansen E, Michels M, Til M, Doelman P. Effects of heavy metals in soil on microbial diversity and activity as shown by the sensitivity-resistance index, an ecologically relevant parameter. Biol Fertility Soils. 1994;17(3):177-84.

6. Azab E, Hegazy AK. Monitoring the Efficiency of Rhazya stricta L. Plants in Phytoremediation of Heavy Metal-Contaminated Soil. Plants. 2020;9(9):1057.

7. Takenaka C, Kobayashi M, Kanaya S. Accumulation of cadmium and zinc in Evodiopanax innovans. Environ Geochem Health. 2008;31(6):609-15.

8. Ma Y, Prasad MNV, Rajkumar M, Freitas H. Plant growth promoting rhizobacteria and endophytes accelerate phytoremediation of metalliferous soils. Biotechnol Adv. 2011;29(2):248-58.

9. Sarwar N, Imran M, Shaheen MR, Ishaque W, Kamran MA, Matloob A, Rehim A, Hussain S. Phytoremediation strategies for soils contaminated with heavy metals: Modifications and future perspectives. Chemosphere Oxford. 2017;171:710-21. 
10. Rouached $\mathrm{H}$. Recent developments in plant zinc homeostasis and the path toward improved biofortification and phytoremediation programs. Plant Signaling Behavior. 2013;8(1):e22681.

11. Chibuike GU, Obiora SC, Liang Y. Heavy Metal Polluted Soils: Effect on Plants and Bioremediation Methods. Applied Environmental Soil Science. 2014;2014(1):1-12.

12. Angle JS, Baker AJM, Whiting SN, Chaney RL. Soil moisture effects on uptake of metals by Thlaspi, Alyssum, and Berkheya. Plant Soil. 2003;256(2):325-32.

13. Achakzai AKK, Liasu MO, Popoola OJ. Effect of mycorrhizal inoculation on the growth and phytoextraction of heavy metals by Maize Grown in Oil Contaminated Soil. Pak J Bot. 2011;44(1):221-30.

14. Wang QR, Cui YS, Liu XM, Dong YT, Christie P. Soil contamination and plant uptake of heavy metals at polluted sites in China. Environ Lett. 2003;38(5):823-38.

15. Anjos SL, Angelo PF, Corrêa NR, Antunes AR. Use of non-hyperaccumulator plant species for the phytoextraction of heavy metals using chelating agents. Scientia Agricola. 2013;70(4):290-5.

16. Maric M, Antonijevic M, Alagic S. The investigation of the possibility for using some wild and cultivated plants as hyperaccumulators of heavy metals from contaminated soil. Environmental Science Pollution Research International. 2013;20(2):1181-8.

17. Watanabe, Myrna E. Phytoremediation on the brink of commericialization. Environmental ence Technology. 1997;31(4):182A-186A.

18. Hermans C, Hammond JP, White PJ, Verbruggen N. How do plants respond to nutrient shortage by biomass allocation? Trends Plant Sci. 2006;11(12):610-7.

19. Sattelmacher B, Klotz F, Marschner H. Influence of the nitrogen level on root growth and morphology of two potato varieties differing in nitrogen acquisition I Titel. 1990, 123(2):131-137.

20. He X, Ma W, Liang C, Hong M, Xin X. Effects of Nutrient Additions on Community Biomass Varied among Different Grassland Ecosystems of Inner Mongolia. Acta Scientiarum Naturalium Universitatis Pekinensis. 2015;51(04):657-66.

21. Huang J, Wang C, Qi L, Zhang X, Tang G, Li L, Guo J, Jia Y, Dou X, Lu M. Phosphorus is more effective than nitrogen in restoring plant communities of heavy metals polluted soils. Environ Pollut. 2020;266(Pt 3):115259.

22. Aggarwal P, Banerjee B, Daryaei M, Bhatia A, Bala A, Rani S, Chander S, Pathak H, Kalra N. InfoCrop: A dynamic simulation model for the assessment of crop yields, losses due to pests, and environmental impact of agro-ecosystems in tropical environments. I. Model description. Agric Syst. 2006;89(1):4767.

23. Gebrekidan H, Seyoum M. Effects of Mineral N and P Fertilizers on Yield and Yield Components of Flooded Lowland Rice on Vertisols of Fogera Plain, Ethiopia. Journal of Agriculture Rural Development in the Tropics Subtropics. 2006;107(2):161-76.

24. MAO J, XING Y, YAN G, WANG Q. A meta-analysis of the response of terrestrial plant biomass allocation to simulated N deposition. Acta Ecol Sin. 2018;38(9):3183-94. 
25. Bai Y, Yan R, Schellenberg MP, Wang H, Han G, Zhang R, Zhang J, Wei Z. Nitrogen increased aboveground biomass of Leymus chinensis grown in semi-arid grasslands of inner Mongolia, China. Agron J. 2020;112(1):511-22.

26. Steven CP. Ecology: The big picture of marsh loss. Nature. 2012;490(7420):352-3.

27. Sofo A, Dichio B, Xiloyannis $C$, Masia A. Lipoxygenase activity and proline accumulation in leaves and roots of olive trees in response to drought stress. Physiol Plant. 2010;121(1):58-65.

28. Song J, Wang Y, Pan Y, Pang J, Zhang X, Fan J, Zhang Y. The influence of nitrogen availability on anatomical and physiological responses of Populus alba $\times$ P. glandulosa to drought stress. BMC Plant Biol. 2019;19(1):63.

29. Lin AJ, Zhang XH, Wong MH, Ye ZH, Lou LQ, Zhu WYG. Increase of multi-metal tolerance of three leguminous plants by arbuscular mycorrhizal fungi colonization. Environmental Geochemistry\&Health. 2007;29(6):473-81.

30. Zhang GB, Yi HY, Gong JM. The Arabidopsis Ethylene/Jasmonic Acid-NRT Signaling Module Coordinates Nitrate Reallocation and the Trade-Off between Growth and Environmental Adaptation. Plant Cell. 2014;26(10):3984-98.

31. Zhang H. The Effect on the Activity of Gracilaria's Antioxidant Enzymes in Different Conditions of Nitrogen and Phosphorus under Cadmium Stress. Environmental Monitoring Forewarning. 2012;4(06):46-9.

32. Schiltz S. Dynamics of exogenous nitrogen partitioning and nitrogen remobilization from vegetative organs in pea revealed by $15 \mathrm{~N}$ in vivo labeling throughout seed filling. Plant Physiol. 2005;137(4):1463-73.

33. Benner JW, Conroy S, Lunch CK, Toyoda N, Vitousek PM. Phosphorus Fertilization Increases the Abundance and Nitrogenase Activity of the Cyanolichen Pseudocyphellaria crocata in Hawaiian Montane Forests. Biotropica. 2007;39(3):400-5.

34. Yang X-X, Ren F, Zhou H-K, He J-S. Responses of plant community biomass to nitrogen and phosphorus additions in an alpine meadow on the Qinghai-Xizang Plateau. chinese journal of plant ecology. 2014;38(2):159-66.

35. Catherine S, Christophe S, Louis MJ. Response of Thlaspi caerulescens to Nitrogen, Phosphorus and Sulfur Fertilisation. Int J Phytoremediation. 2006;8(2):149-61.

36. Robinson BH, Leblanc M, Petit D, Brooks RR, Kirkman JH, Gregg PEH. The potential of Thlaspi caerulescens for phytoremediation of contaminated soils. Plant Soil. 1998;203(1):47-56.

37. Liao X-Y, Chen T-B, Xiao X-Y, Xie H, Yan X-L. Selecting Appropriate Forms of Nitrogen Fertilizer to Enhance Soil Arsenic Removal byPteris Vittata: A New Approach in Phytoremediation. Int $\mathrm{J}$ Phytoremediation. 2007;9(4):269-80.

38. Zavaleta ES, Shaw MR, Chiariello NR, Thomas BD, Cleland EE, Field CB, Mooney HA. GRASSLAND AND RESPONSES TO THREE YEARS OF ELEVATED TEMPERATURE, CO[sub 2], PRECIPITATION, AND N DEPOSITION. Ecol Monogr. 2003;73(4):585-604. 
39. Henry HAL, Chiariello NR, Vitousek PM, Mooney HA, Field CB. Interactive Effects of Fire, Elevated Carbon Dioxide, Nitrogen Deposition, and precipitation on a California Annual Grassland. Ecosystems. 2006;9(7):1066-75.

40. Niu K, Luo Y, Choler P, Du G. The role of biomass allocation strategy in diversity loss due to fertilization. Basic Applied Ecology. 2008;9(5):485-93.

41. Vladimir K, Marcel B. Symbiotic phosphate transport in arbuscular mycorrhizas. Trends Plant Sci. 2005;10(1):22-9.

42. Zhang W. Zhong: Nitrogen as an important detoxification factor to cadmium stress in poplar plants. J Plant Interact. 2014;9(1):249-58.

43. Anyanwu B, Ezejiofor A, Igweze Z, Orisakwe O. Heavy Metal Mixture Exposure and Effects in Developing Nations: An Update. Toxics. 2018;6(4):65.

44. Wei S, Silva JATd, Zhou Q. Agro-improving method of phytoextracting heavy metal contaminated soil. J Hazard Mater. 2008;150(3):662-8.

45. Eriksson JE. Effects of nitrogen-containing fertilizers on solubility and plant uptake of cadmium. Water Air Soil Pollution. 1990;49(3):355-68.

46. Bogdanovic D, Ubavic M, Cuvardic M. Effect of phosphorus fertilization on Zn and Cd contents in soil and corn plants. Nutr Cycl Agroecosyst. 1999;54(1):49-56.

47. Hu Y, Norton GJ, Duan G, Huang Y, Liu Y. Effect of selenium fertilization on the accumulation of cadmium and lead in rice plants. Plant Soil. 2014;384(1-2):131-40.

48. Dheri GS, Brar MS, MalhI SS. Influence of phosphorus application on growth and cadmium uptake of spinach in two cadmium-contaminated soils. J Plant Nutr Soil Sci. 2007;170(4):495-9.

49. Wångstrand $H$, Eriksson J, Öborn I. Cadmium concentration in winter wheat as affected by nitrogen fertilization. Eur J Agron. 2007;26(3):209-14.

50. Zhang XL, Yang Q. Influence of Nitrogen Nutrients on Hyperaccumulation of Sedum alfredii Hance under Complex Heavy Metals Stress. Adv Mater Res. 2013;2914(864-867):190-3.

51. Grant CA, Sheppard SC. Fertilizer Impacts on Cadmium Availability in Agricultural Soils and Crops. Human Ecological Risk Assessment: An International Journal. 2008;14(2):210-28.

52. Atafar Z, Mesdaghinia A, Nouri J, Homaee M, Yunesian M, Ahmadimoghaddam M, Mahvi AH. Effect of fertilizer application on soil heavy metal concentration. Environ Monit Assess. 2010;160(1-4):83.

53. THORNLEY JHM. A Balanced Quantitative Model for Root: Shoot Ratios in Vegetative Plants. THORNLEY J H M. 1972;36(2):431-41.

54. Peng Y, Peng Z, Zeng X, Houx JH. Effects of nitrogen-phosphorus imbalance on plant biomass production: a global perspective. Plant Soil. 2019;436(1-2):245-52.

55. WEN Z, SHEN J, Martin B, LI H, ZHAO B. YUAN H: Combined Applications of Nitrogen and Phosphorus Fertilizers with Manure Increase Maize Yield and Nutrient Uptake via Stimulating Root Growth in a Long-Term Experiment. Pedosphere. 2016;26(1):62-73. 
56. Aerts R, Chapin FS: The Mineral Nutrition of Wild Plants Revisited: A Re-evaluation of Processes and Patterns. In: Adv Ecol Res. Edited by Fitter AH, Raffaelli DG, vol. 30: Academic Press; 1999: 1-67.

57. Nriagu JO, Pacyna JM. Quantitative assessment of worldwide contamination of air, water and soils by trace metals. Nature. 1988;333(6169):134-9.

58. Piqueray J, Gilliaux V, Decruyenaere V, Cornelis J-T, Uyttenbroeck R, Mahy G. Management of Grassland-like Wildflower Strips Sown on Nutrient-rich Arable Soils: The Role of Grass Density and Mowing Regime. Environ Manage. 2019;63(5):647-57.

\section{Figures}




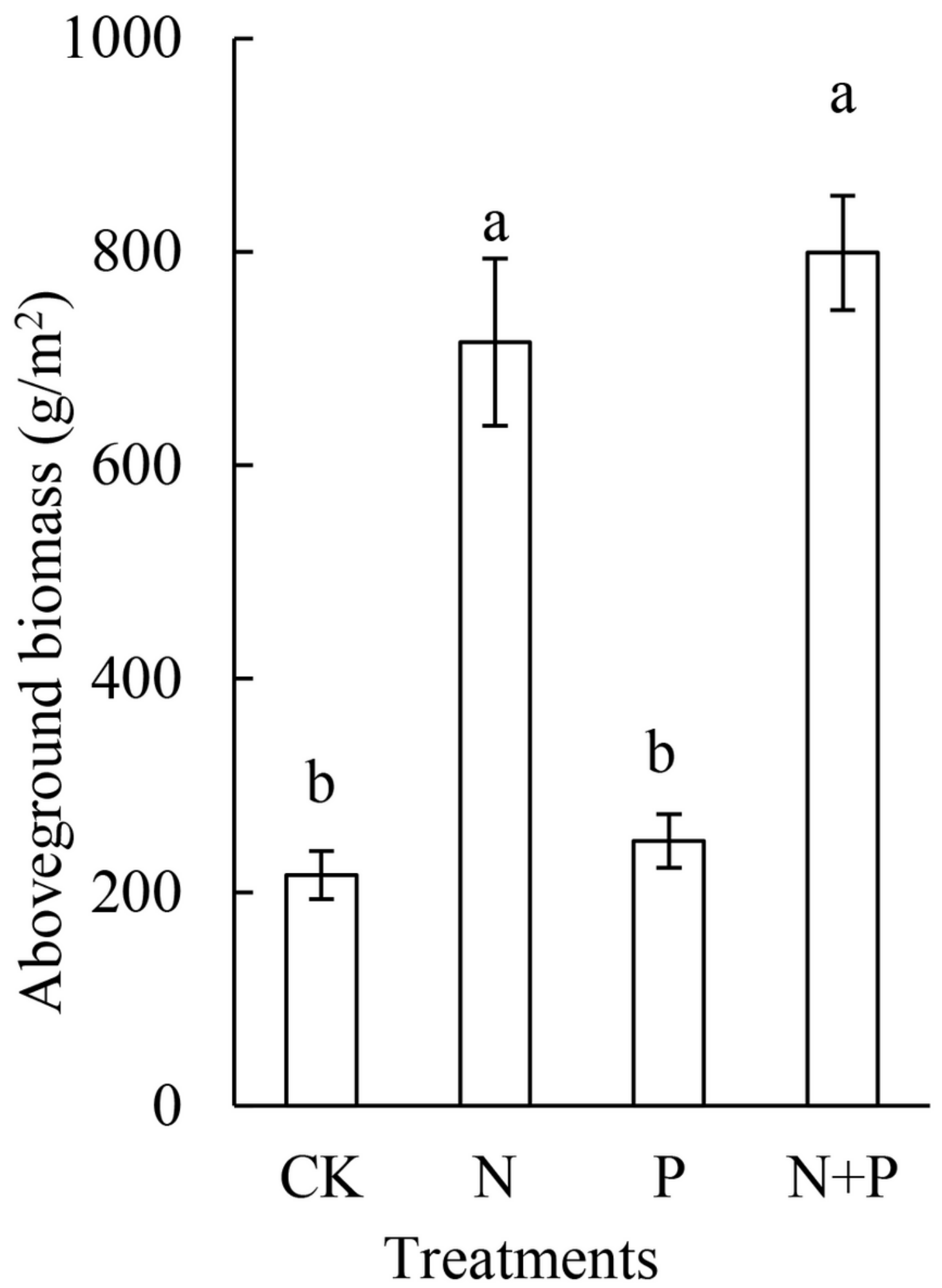

Figure 1

Plant aboveground biomass per unit area under different treatments. 


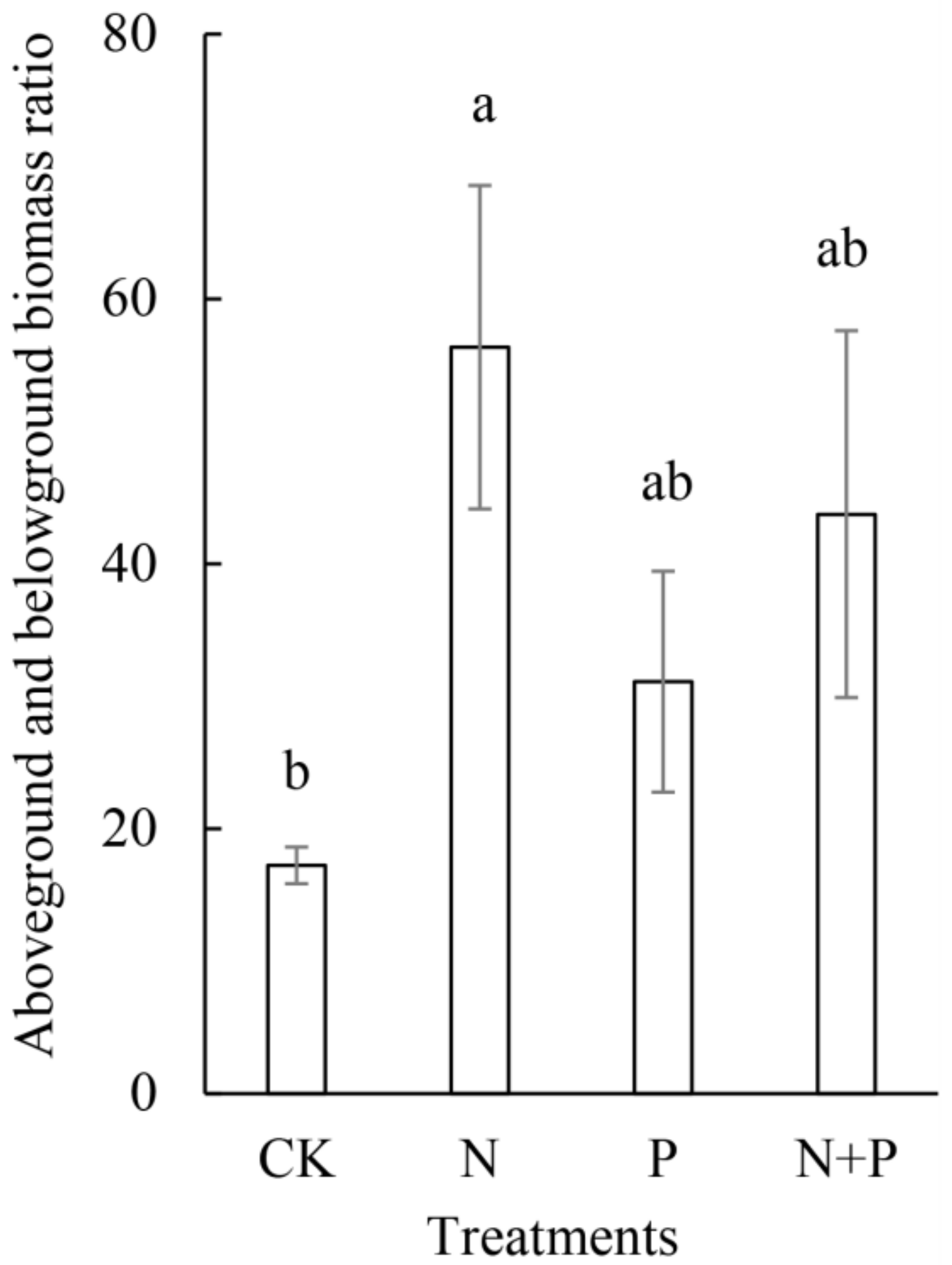

Figure 2

Plant aboveground and belowground biomass ratio of different treatments. 

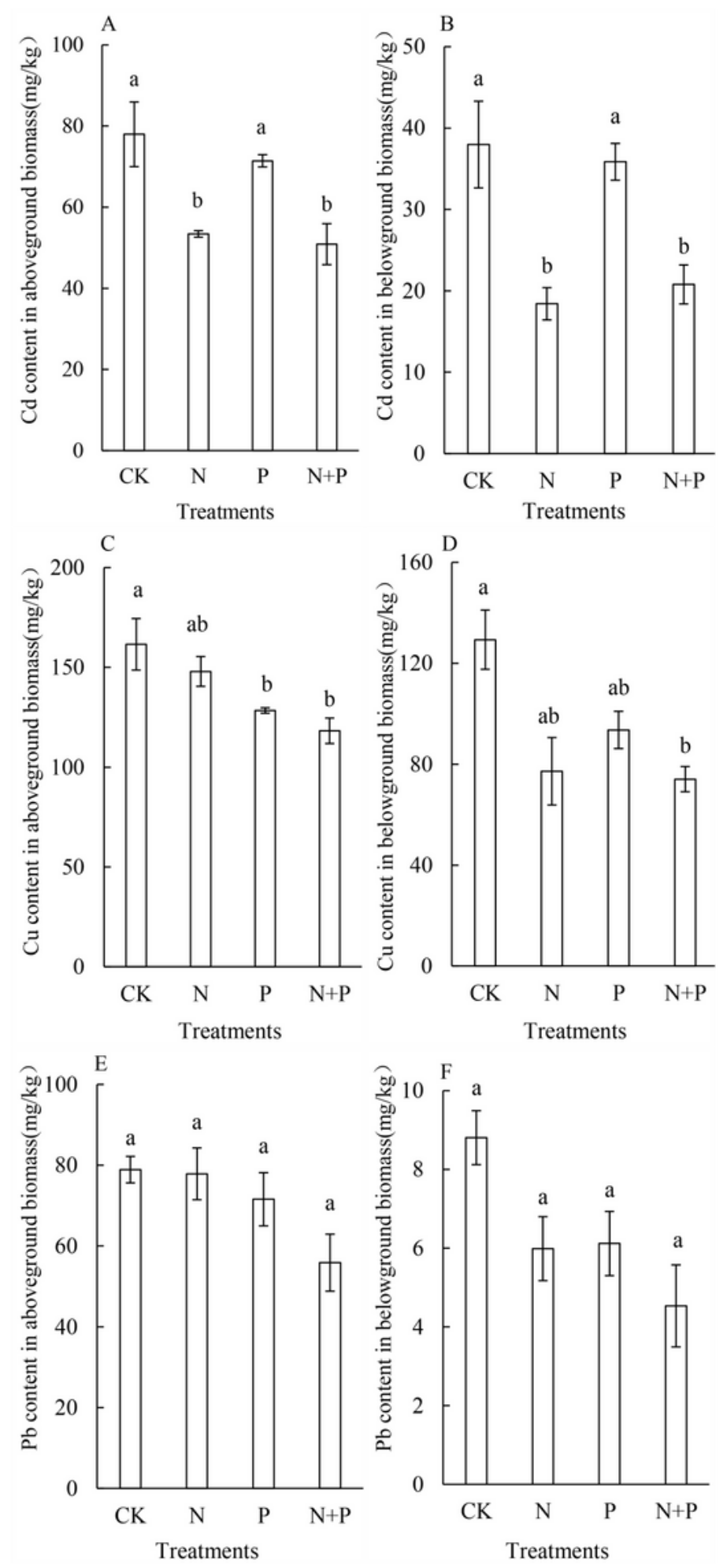

Figure 3

Plant aboveground $(A, C, E)$ and belowground $(B, D, F)$ biomass heavy metals content. 

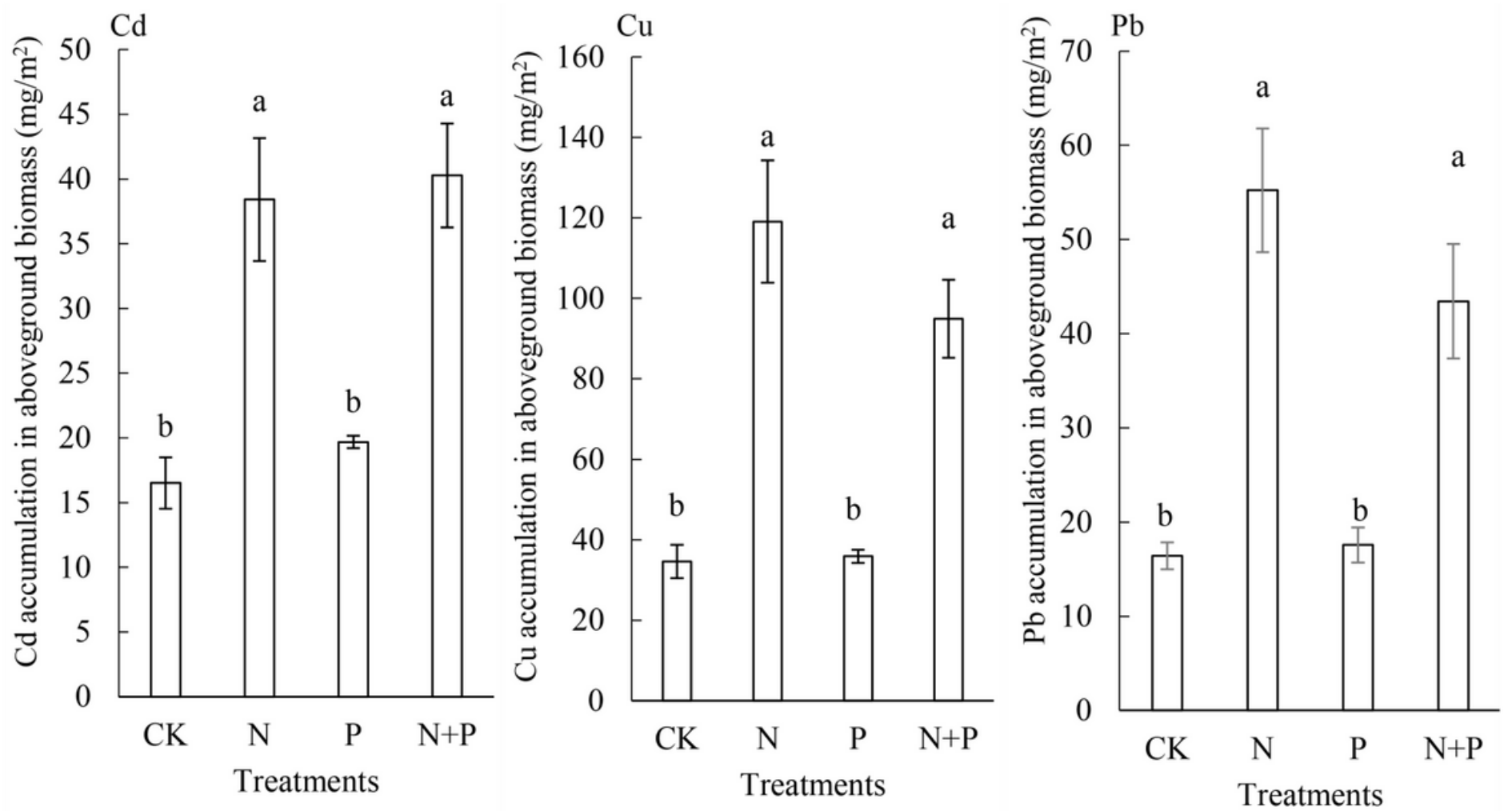

Figure 4

Heavy metals accumulation in aboveground biomass. 

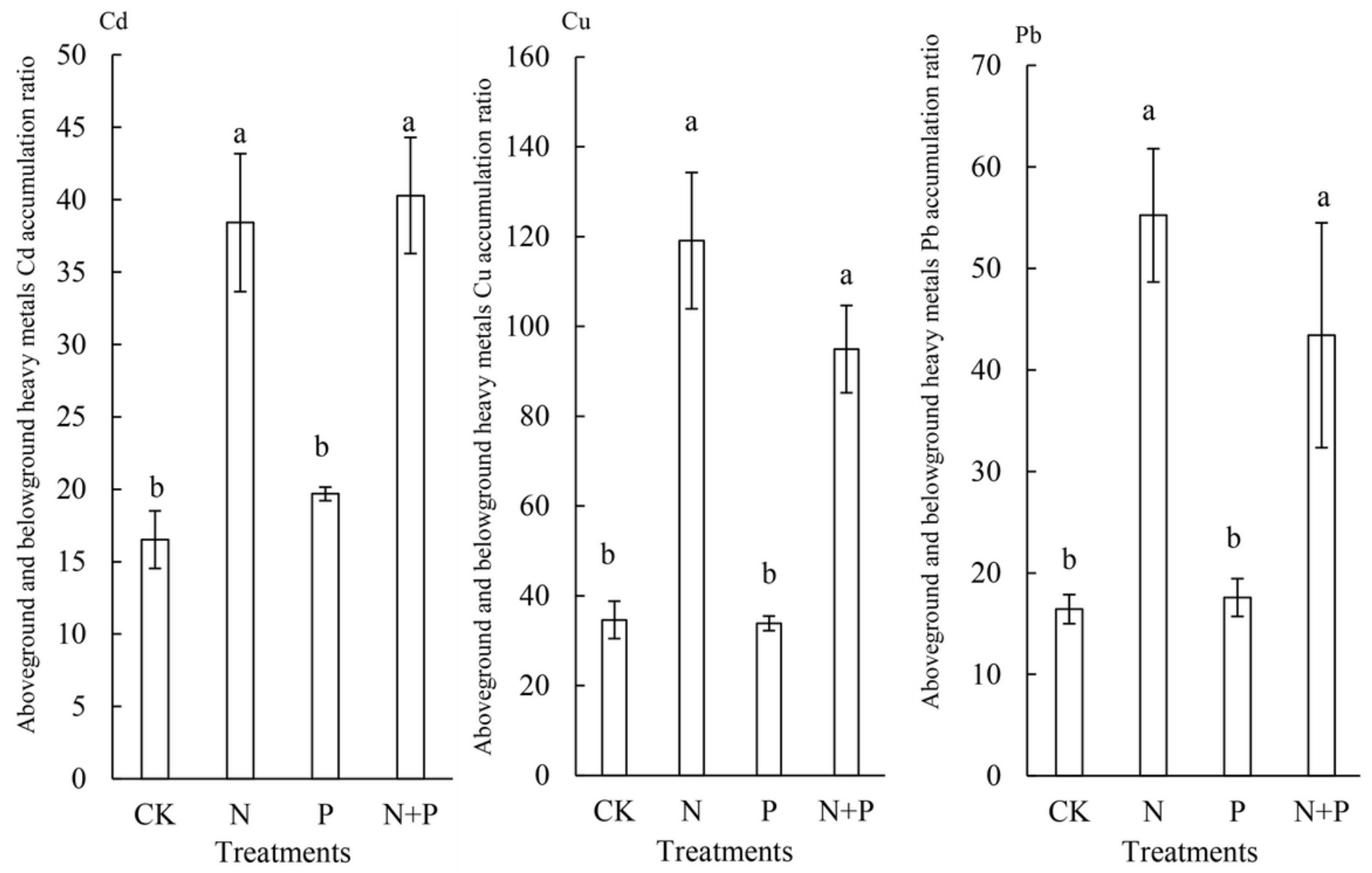

Figure 5

Aboveground and belowground heavy metals accumulation ratio. 